\title{
Does Economic Growth Need Democracy? An Application on Islamic Countries with System-GMM Approach
}

\author{
Kaya MUHAMMED VEYSEL ${ }^{\star}$, Yllmaz SUAT SERHAT ${ }^{\star \star}$
}

\begin{tabular}{l}
\multicolumn{1}{c}{ A R T I C L E I N F O } \\
\hline Article history: \\
Accepted February 2019 \\
Available online April 2019 \\
\hline JEL Classification \\
O40, D71, E21 \\
Keywords: \\
Generalized Moment Methods, \\
Democracy, Islamic Countries
\end{tabular}

\begin{abstract}
A B S T R A C T
There is growing body of literature over the last decade years examining the question "Does democracy induce economic performance or slow it down? If so, what way it does? This relationship studied by social scientists especially since 19 th centuries have been become more of an issue with democracy movements occurring middle east. Previous studies have pointed out there may exist the existence of either positive or negative relationship between these two variables. The proponents of democratization put forward that the democracy fosters economic growth by increasing the accumulation of human capital, reducing income inequality, providing with political stability and preventing social disasters. In this context, this paper searches for this relationship based on Islamic Countries containing totally 49 countries. The study covers data for years between 2010 and 2016 and analysis this relationship through Generalized Moment Methods (GMM). The results of this study show that there is a positive relationship between them and one-point increase in democracy index causes averagely 0.45 basis point rise on the growth of GDP Per Capita for related countries.
\end{abstract}

(C) 2019 EAI. All rights reserved.

\section{Introduction}

Although the democracy is accepted generally as phenomenon affecting directly social justice, equal participation and political rights in first plan, it is also important for economists to determine real-life and material effects on economic growth and development of countries. The results of investigations about this topic centred on the debates for last 50 years yield inconclusive and ambiguous answers in terms of estimating the effects of democracy on economic growth and development (Doucouliagos and Ulubaşoğlu, 2008).

The advocators of democratization assert that the democracy contribute to economic growth by increasing human capital, decreasing income inequality, providing with political stability and preventing social disasters. For this group, democracy is regarded as a precondition of economic development. On the other hand, the opposing views put forward the autocratic regimes results in more economic growth and development on account of the fact that these regimes can exert pressure on current consumption and increase savings, thereby raising investments, and finally growth. In addition to these, the dictators, by the reason of being more independent in determining politics, pave the way for better sight of priorities of economic developments and, in this way, lead to economic growth and development (Dogan, 2005).

Apart from these two approaches, there is also another view called "sceptical approach", suggesting that a systematic relationship between growth and democracy should not be sought, but rather should focus on specific policies and institutional arrangements. What is important here is the level of individual freedoms rather than the nature of political processes. There is no guarantee that individual freedoms will continue to be so in democratic regimes, even more than in autocratic regimes (Sirowy and Inkeles, 1990).

The aim of this paper is to estimate and determine the coefficients of the democracy on economic growth with an econometric analysis by System Generalized Moments Method (System GMM) based on data for 49 Islamic Countries, the members of Organization of Islamic Corporation (OIC). In terms of selected county group, it is first study come across in this literature, measuring these relations in the context of Islamic countries. The study utilizes from the data of the variables like GDP Per Capita as dependent variable; democracy index, final consumption expenditures, trade openness, inflation rate, population growth, financial depth as independent variables.

\footnotetext{
${ }^{\star},{ }^{\star \star}$ Kirikkale University, Kırıkkale, Turkey. E-mail addresses: mveyselkaya@yahoo.com (K. M. Veysel - Corresponding author), suatserhatyilmaz@gmail.com (I.S. Serhat)
} 


\section{Literature review}

Many studies have been done in the literature. Dates, countries, methods and results covered by these studies are presented chronologically in the Table 1 below.

Table 6. Previous Studies

\begin{tabular}{|c|c|c|c|c|}
\hline Authors & $\begin{array}{l}\text { Date } \\
\text { Range }\end{array}$ & Sample Size & Method & Results and Relationship \\
\hline $\begin{array}{l}\text { Heshamti and Kim } \\
\text { (2017) }\end{array}$ & $\begin{array}{c}\text { 1980-2014 } \\
\text { Annually }\end{array}$ & $\begin{array}{l}\text { Panel Data } \\
144 \\
\text { Countries } \\
\end{array}$ & $\begin{array}{c}\text { Single, Multiple Time Trends } \\
\text { and General Index } \\
\text { Formulations }\end{array}$ & Positive relation \\
\hline $\begin{array}{l}\text { Gründeler and and } \\
\text { Krieger (2016) }\end{array}$ & $\begin{array}{l}\text { 1981-2011 } \\
\text { Annually }\end{array}$ & $\begin{array}{l}\text { Panel Data } \\
185 \\
\text { Countries }\end{array}$ & Support Vector Machines & Positive relation \\
\hline Salahodjaev (2015) & $\begin{array}{l}\text { 1970-2013 } \\
\text { Annually }\end{array}$ & $\begin{array}{l}\text { Panel Data } \\
93 \text { Countries }\end{array}$ & Ordinary Least Squares & $\begin{array}{l}\text { The relationship varying } \\
\text { depending on nation's level } \\
\text { of cognitive abilities / } \\
\text { positive relation }\end{array}$ \\
\hline Rachdi and Saidi (2014), & $\begin{array}{l}\text { 1983-2012 } \\
\text { Annually }\end{array}$ & $\begin{array}{l}\text { Panel Data } \\
37 \text { Countries }\end{array}$ & $\begin{array}{l}\text { Random Effect } \\
\text { Fixed Effect } \\
\text { System GMM } \\
\end{array}$ & Negative Relation \\
\hline Narayan et. al (2011) & $\begin{array}{l}\text { 1972-2001 } \\
\text { Annually }\end{array}$ & $\begin{array}{l}\text { Panel Data } \\
30 \text { Countries }\end{array}$ & Granger Causality Test & $\begin{array}{l}\text { Two-way Causality/ } \\
\text { Negative effect from } \\
\text { democracy and GDP }\end{array}$ \\
\hline Knutsen (2011) & $\begin{array}{l}\text { 1820-2002 } \\
\text { Annually }\end{array}$ & $\begin{array}{l}\text { Panel Data } \\
100 \\
\text { Countries }\end{array}$ & $\begin{array}{c}\text { Ordinary Least Square } \\
\text { Fixed Effect } \\
\text { Panel Corrected Standard } \\
\text { Errors } \\
\end{array}$ & No Effect \\
\hline Tanga and Yung (2008) & $\begin{array}{c}1970-1996 \\
\text { Annually }\end{array}$ & $\begin{array}{l}\text { Panel Data } \\
8 \text { Countries }\end{array}$ & ARDL Model & Positive Effect, not always. \\
\hline Firdmuc (2003) & $\begin{array}{c}\text { 1990-2000 } \\
\text { Annually }\end{array}$ & $\begin{array}{c}\text { Panel Data } \\
25 \text { Countries }\end{array}$ & Ordinary Least Squares & $\begin{array}{l}\text { Varying effect depending on } \\
\text { the progress of liberalization } \\
\text { of foreign trade. }\end{array}$ \\
\hline Kurzman et al. (2002) & $\begin{array}{l}\text { 1951-1980 } \\
\text { Annually }\end{array}$ & $\begin{array}{c}\text { Panel Data } \\
106 \\
\text { Countries }\end{array}$ & Ordinary Least Squares & Slightly positive effect \\
\hline $\begin{array}{l}\text { Tavares and Wacziang } \\
(2001)\end{array}$ & $\begin{array}{c}\text { 1970-1989 } \\
\text { Annually }\end{array}$ & $\begin{array}{c}\text { Panel Data } \\
65 \text { Countries }\end{array}$ & $\begin{array}{c}\text { Fixed Effects } \\
\text { Joint System Estimates }\end{array}$ & $\begin{array}{l}\text { Negative relation and } \\
\text { moderate Effect }\end{array}$ \\
\hline Barro (1996) & $\begin{array}{l}\text { 1960-1990 } \\
\text { Annually }\end{array}$ & $\begin{array}{c}\text { Panel Data } \\
100 \\
\text { Countries }\end{array}$ & Regression & Weakly negative \\
\hline
\end{tabular}

In this field, the pioneer study was made by Barro (1996) so as to measure the relations between democracy and economic growth. This study found that, statically, there is weakly negative relationship between these variables. As seen above, Heshamti and Kim (2017), Gründler and Krieger (2016), Tanga and Yung and Kurzman et al. (2002) also probed the relationship between democracy and economic growth in their studies. The results of their studies point out that the variable democracy affects economic growth in positive way. For the same relationship, Salahodjaev (2015) and Firdmuc (2003) found varying relations depending on different factors like cognitive abilities and the progress of liberalization of foreign trade. Conversely, Rachdi and Saidi (2014), Narayan et. Al (2011) and Tavares and Wacziang (2001) reached the to the results implying negative relationship between these variables. Finally, Knutsen (2011) found that there appears no effect democracy on the economic growth.

\section{Data Set, Model and Method}

The data set of this paper contains 49 Islamic countries (Afghanistan, Albania, Algeria, Azerbaijan, Bahrain, Bangladesh, Benin, Burkina Faso, Cameroon, Chad, Comoros, Djibouti, Egypt, Arab Rep., Gabon, Guinea, Guinea-Bissau, Guyana, Indonesia, Iran, Islamic Rep., Iraq, Jordan, Kazakhstan, Kuwait, Kyrgyz Republic, Lebanon, Malaysia, Mali, Mauritania, Morocco, Mozambique, Niger, Nigeria, Pakistan, Qatar, Saudi Arabia, Senegal, Sierra Leone, Sudan, Suriname, Tajikistan, Togo, Tunisia, Turkey, Turkmenistan, Uganda, United Arab Emirates, Uzbekistan, West Bank and Gaza, Yemen, Rep), the member of Organization Islamic Corporation (OIC). The time dimension of data covers annually the years between 2010 and 2016, which are limited by available democracy index data published by Economic Intelligence Unit (EIU). The variables used in the paper are taken into models and they are designed by following Rachdi and Saidi (2015).

The variables, their definitions, abbreviations and sources used in analysis are given below Table 2 . 
Table 2. Data Set

\begin{tabular}{|c|c|c|c|c|c|}
\hline \multirow{2}{*}{$\begin{array}{l}\text { Variables Used in Models } \\
\text { GDP Per Capita }\end{array}$} & \multirow{2}{*}{\multicolumn{2}{|c|}{$\begin{array}{c}\text { Abbreviations } \\
\text { GDP }\end{array}$}} & \multicolumn{3}{|c|}{ Definition of the Variables } \\
\hline & & & \multicolumn{3}{|c|}{ Annual percentage growth rate of GDP per capita. } \\
\hline \multicolumn{2}{|l|}{ Democracy Index ${ }^{1}$} & DEM & \multicolumn{3}{|c|}{$\begin{array}{l}\text { It is The Economist Intelligence Unit's Democracy } \\
\text { Index, scored on a scale of } 0 \text { to } 10 \text { and based on } 60 \\
\text { indicators. }\end{array}$} \\
\hline \multicolumn{2}{|l|}{$\begin{array}{l}\text { Final Consumption } \\
\text { Expenditures (\%GDP) }{ }^{2}\end{array}$} & GOV & \multicolumn{3}{|c|}{$\begin{array}{l}\text { General government final consumption expenditure as } \\
\text { a percentage of GDP }\end{array}$} \\
\hline \multicolumn{2}{|l|}{ Trade Openness ${ }^{2}$} & TRA & \multicolumn{3}{|c|}{$\begin{array}{l}\text { it is the sum of exports and imports of goods and } \\
\text { services measured as a share of GDP }\end{array}$} \\
\hline \multicolumn{2}{|l|}{ Inflation Rate ${ }^{2}$} & INF & \multicolumn{3}{|c|}{ Annual inflation rate } \\
\hline \multicolumn{2}{|l|}{ Population Growth $(\%)^{2}$} & POP & \multicolumn{3}{|c|}{ Annual population growth rate } \\
\hline \multicolumn{2}{|l|}{ Financial Depth ${ }^{2}$} & FIN & \multicolumn{3}{|c|}{$\begin{array}{l}\text { It is a proxy variable for financial depth, measured as } \\
\text { domestic credits to private sector (\% of GDP) }\end{array}$} \\
\hline \multicolumn{6}{|c|}{$\begin{array}{l}\text { Notes: } \\
{ }^{1} \underline{\text { https://infographics.economist.com/2017/DemocracyIndex/, Date Accessed: } 14.12 .2017 .} \\
{ }^{2} \underline{\text { http://databank.worldbank.org/data/reports.aspx? source=world-development-indicators, }} \text {, Date Accessed: } 14.12 .2017 .\end{array}$} \\
\hline \multicolumn{6}{|c|}{$\begin{array}{l}\text { Our key and independent variable in the analysis is Democracy index compiled by the Economist Intelligence } \\
\text { Unit's, scored on a scale of } 0 \text { to } 10 \text { and based on } 60 \text { indicators. As a component, Index has five categories aiming } \\
\text { to comprehend all different dimensions of democracy. They are Electoral Process and Pluralism, Functioning of } \\
\text { Government, Political Participation, Political Culture and Civil Liberties. Additionally, the countries scored by the } \\
\text { index between } 1 \text { and } 4 \text { are classified as authoritarian regimes. Those between } 4 \text { and } 6 \text { are hybrid regimes, those } \\
\text { between } 6 \text { and } 8 \text { and are flawed democracies and, finally, those above } 8 \text { are accepted as full democracies. Table } \\
3 \text { presents summary statistics of the variables used in models. }\end{array}$} \\
\hline \multicolumn{6}{|c|}{ Table 3. Summary Statistics } \\
\hline Variable & Obs & Mean & Std. Dev. & Min & Max \\
\hline GDP & 339 & 1.805475 & 4.17637 & -29.88633 & 17.9967 \\
\hline DEM & 343 & 3.970117 & 1.452534 & 1.262255 & 7.032493 \\
\hline GOV & 313 & 14.41677 & 4.970721 & 4.426712 & 30.11914 \\
\hline TRA & 325 & 78.79786 & 34.87245 & 19.10008 & 205.261 \\
\hline INF & 324 & 5.257746 & 6.393807 & -8.11517 & 52.33562 \\
\hline FIN & 319 & 34.01219 & 26.38349 & 3.598476 & 125.1471 \\
\hline POP & 343 & 2.479741 & 1.36745 & -0.496462 & 11.22069 \\
\hline
\end{tabular}

As seen above, the maximum and minimum score of Democracy Index are 7.03 and 1.26, respectively taken by Indonesia and Guinea- Bissau. As for the average of democracy index, it is 3.970117, meaning that Islamic Countries included classified as having autoritarian regimes. According to Democracy Index Report (2015), it means that there is no state political pluralism or strongly restricted in this group of countries. Although, in this type of regimes, some formal institutions of democracy can exist, they have little importance. Elections occurring in the countries for this category may not be fair and free. There can be disregard for abuses and infringements of civil liberties, media typically state-owned or controlled by groups and repression of criticism of the government and pervasive censorship, outright dictatorships and not be independent judiciary for this group of countries.

In the study, System-GMM Method is used in estimation of model. The different models to estimate based on the GMM method is presented below.

$$
\begin{aligned}
& G D P_{i t}=\alpha+\beta_{0} G D P_{i t-1}+\beta_{1} D E M_{i t}++\beta_{2} T R A_{i t}+\beta_{3} I N F_{i t}+\beta_{4} P O P_{i t}+\mu_{i t}+\lambda_{t}+\varepsilon_{i t} \\
& G D P_{i t}=\alpha+\beta_{0} G D P_{i t-1}+\beta_{1} D E M_{i t}+\beta_{2} F I N_{i t}+\beta_{3} P O P_{i t}+\mu_{i t}+\lambda_{t}+\varepsilon_{i t} \\
& G D P_{i t}=\alpha+\beta_{0} G D P_{i t-1}+\beta_{1} D E M_{i t}++\beta_{2} T R A_{i t}+\beta_{3} F I N_{i t}+\beta_{4} P O P_{i t}+\mu_{i t}+\lambda_{t}+\varepsilon_{i t} \\
& G D P_{i t}=\alpha+\beta_{0} G D P_{i t-1}+\beta_{1} D E M_{i t}+\beta_{2} T R A_{i t}+\beta_{3} I N F_{i t}+\beta_{4} F I N_{i t}+\beta_{5} P O P_{i t}+\mu_{i t}+\lambda_{t}+\varepsilon_{i t}
\end{aligned}
$$




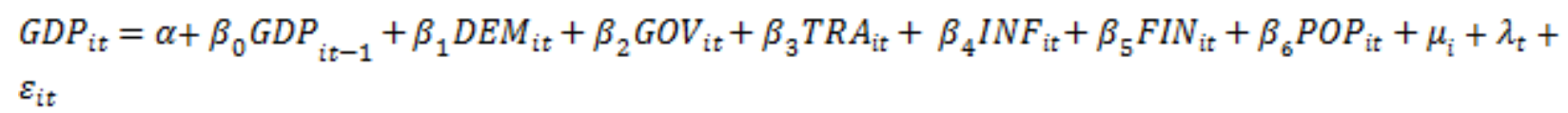

where the dependent variable $G D P_{i t}$ is Gross Domestic Product Per Capita Growth, ${ }^{G D P_{i t-1}}$ is one-lagged values of GDP, $D E M_{i t}$ is Democracy Index scored on 1-10, $G O V_{i t}$ is General Government Final Consumption Expenditure as a percentage of GDP, ${ }^{T R A_{i t}}$ is the sum of exports and imports of goods and services measured as a share of GDP, $I N F_{i t}$ is Annual Inflation Rates, $F I N_{\text {it }}$ is proxy variable for financial depth, measured as Domestic Credits To Private Sector as a percentage of GDP, ${ }^{P O P_{i t}}$ is Annual Population Growth Rates for related countries, $\lambda_{\mathrm{t}}$ is unobservable time-specific effects, $\mu_{\mathrm{i}}$ is unobservable unit-specific effects and finally, $\varepsilon_{\mathrm{t}}$ is disturbance terms. To control the changes of the coefficients of democracy index is used different combinations of this models by adding and removing some these variables.

The System-GMM approach used in the analysis was developed by Arellano and Bover (1995), based on combining the difference equation and the level equations. Blundell and Bond (1998) and Blundell et al. (2001) have shown that the difference-GMM is has a weak estimation power for finite samples and that the coefficient estimates obtained by using this method are biased, meaning that the System-GMM has a higher estimation power in comparison with normal GMM. For this reason, the GMM approach, which is expressed as a better predictor when compared to other GMM estimators, has been used in the study.

\section{Findings}

In this part of the study including the econometric application, the relationship GDP Per Capita and Democracy Index between is estimated by the System GMM method, a dynamic panel data analysis method. In this process, firstly the binary correlations between the variables will be examined and interpreted by giving the estimation results obtained. Table 4 gives the binary correlations for the variables used in the analysis.

Table 4. Pairwise Correlations of the Variables Used

\begin{tabular}{lccccccc}
\hline Variable & GDP & DEM & GOV & TRA & INF. & FIN & POP \\
\hline GDP & 1.000 & --- & --- & --- & --- & -- & --- \\
DEM & 0.0210 & 1.000 & --- & --- & --- & -- & --- \\
GOV & -0.0551 & 0.0789 & 1.000 & --- & --- & --- & --- \\
TRA & -0.0059 & 0.0802 & $0.2457^{*}$ & 1.000 & --- & -- & --- \\
INF & -0.0582 & $-0.1237^{*}$ & $-0.3214^{*}$ & $-0.2982^{*}$ & 1.000 & --- & --- \\
FIN & $-0.1207^{*}$ & $0.2530^{*}$ & $0.1603^{*}$ & $0.5517^{*}$ & $-0.1666^{*}$ & 1.000 & --- \\
POP & $-0.2233^{*}$ & $-0.1802^{*}$ & 0.1049 & 0.0842 & $-0.1781^{*}$ & 0.0370 & 1.000 \\
\hline
\end{tabular}

In the table, it is seen that DEM variable is positively correlated with GDP and there is not a high degree of correlation between the variables, pointing out multicollinearity in the model. Table 5 shows dynamic regression analysis results.

Table 5. System GMM Estimation Results Dependent Variable: GDP 


\begin{tabular}{lcccccc}
\hline \multicolumn{7}{c}{ Dependent Variable: GDP } \\
\hline Variables & $(1)$ & $(2)$ & $(3)$ & $(4)$ & $(5)$ & $(6)$ \\
\hline POP & $-0.3123^{*}$ & $-0.2692^{*}$ & $-0.3707^{* *}$ & & $-0.3312^{*}$ & -0.2641 \\
& $(0.169)$ & $(0.149)$ & $(0.154)$ & & $(0.170)$ & $(0.195)$ \\
\hline Observations & 277 & 270 & 261 & 245 & 259 & 245 \\
Number of Units & 48 & 47 & 46 & 44 & 46 & 44 \\
AR(1) & $-2.58^{* * *}$ & $-2.46^{* * *}$ & $-2.57^{* * *}$ & $-2.61^{* * *}$ & $-2.64^{* * *}$ & $-2.59^{* * *}$ \\
AR(2) & $-1,08$ & -0.89 & $-0,91$ & -0.88 & -0.88 & -0.88 \\
Hansen Statistic & 22.92 & 23.51 & 23.85 & 22.14 & 22.39 & 21.50 \\
Wald Chi-Square & $136.5^{* * *}$ & $141.24^{* * *}$ & $146.48^{* * *}$ & $208.16^{* * *}$ & $169.72^{* * *}$ & $201.06^{* * *}$ \\
\hline The
\end{tabular}

The probability values of autocorrelation test proposed by Arellano and Bond (1991) for AR(2) are above \%10 meaning the absence of second order correlation between error terms. The probability values of Wald statistic are below $1 \%$, signifying that the independent variables used in the model are meaningful wholly. Finally, the probability values of the Hansen Test statistics are higher than $10 \%$, displaying that overidentifying restrictions are valid for instrument variables. Standard errors are in parentheses ${ }^{* * *} \mathrm{p}<0.01,{ }^{* *} \mathrm{p}<0.05$, * $\mathrm{p}<0.1$

Considering the estimations of democracy index for all models, the coefficients of democracy index are positive and statistically significant in at least $\% 5$ confidence level and one basis point increase in this index causes $0,45 \%$ averagely rise in GDP Per capita. The variables financial depth, population, inflation and government size negatively affect democracy index as expected considering previous studies. Beside it, the fact that all different models give similar and close results can imply to the consistency of coefficient of Democracy Index.

\section{Conclusion and Evaluation}

The economy field having aimed to the reasons of macroeconomic performance differences between countries by endeavouring to explain it with real production factors, from the beginning of the 1990s, has started to seek these differences by attributing it to non-material factors like democracy degree. After this seekings, this variable has been used generally in the studies as explanatory variable for economic growth. It is considered that Democracy fosters economic growth by increasing human capital accumulation, reducing income inequality, ensuring political stability and preventing social disasters.

This paper aims to find the answer of the question "what is the effect of democracy on economic growth?" by utilizing from the data for 49 Islamic Countries for the period 2010-2017, through GMM in system. Because of selected county group, this study is first come across in this literature, in terms of measuring these relations in the context of Islamic countries. The study uses the data of the variables like GDP Per Capita as dependent variable; democracy index, final consumption expenditures, trade openness, inflation rate, population growth, financial depth as independent variables. As the method, the System-GMM approach used in the analysis was developed by Arellano and Bover (1995). This method has a higher estimation power in comparison with normal GMM, having a weak estimation power for finite samples.

Our main results for all different models show that the effect of democracy on economic growth is positive and statistically significant. It means that Islamic countries which aims to increase their growth rate must upgrade democratic features. The findings of this paper are similar to those reached by Heshamti and Kim (2017), Gründeler and Krieger (2016), Tanga and Yung (2008), Kurzman et al. (2002) and Salahodjaev (2015). Beside this, the variables financial depth, population, inflation and government size negatively affect democracy index as expected considering previous studies.

\section{References}

1. Arellano, M., and Bover, O. (1995), "Another Look at the Instrumental Variable Estimation of Error-Components Models". Journal of Econometrics, 68(1), pp. 29-51.

2. Barro, R. J. (1996). "Democracy and Growth". Journal of economic growth, 1(1), pp. 1-27.

3. Blundell, R., and Bond, S. (1998), Initial Conditions and Moment Restrictions in Dynamic Panel Data Models. Journal of Econometrics, 87(1), pp. 115-143.

4. Blundell, R., Bond, S., and Windmeijer, F. (2001), "Estimation in Dynamic Panel Data Models: Improving on the Performance of the Standard GMM Estimator". In Nonstationary Panels, Panel Cointegration, and Dynamic Panels, pp. 53-91. Emerald Group Publishing Limited.

5. Doğan, A. (2005), "Demokrasi ve Ekonomik Gelişme”. Erciyes Üniversitesi Íktisadi ve İdari Bilimler Fakültesi Dergisi, (25), pp. 1-19.

6. Democracy Index Report. (2015), https://www.yabiladi.com/img/content/EIU-Democracy-Index-2015.pdf. Date Accessed: 8.12.2017.

7. Doucouliagos, H., and Ulubașoğlu, M. A. (2008). Democracy and Economic Growth: A Meta-Analysis. American Journal of Political Science, 52(1), pp. 61-83.

8. Economic Intelligence Unit. Democracy Index, https://infographics.economist.com/2017/DemocracyIndex/. Date Accessed: 9.12.2017.

9. Firdmuc, J. (2003), "Economic Reform, Democracy and Growth During Post-Communist Transition". European Journal of Political Economy, 19(3), pp. 583-604.

10. Gründler, K., and Krieger, T. (2016), "Democracy and Growth: Evidence from a Machine Learning Indicator". European Journal of Political Economy, 45: 85-107. 
11. Heshmati, A. and Kim, N. S. (2017), "The Relationship between Economic Growth and Democracy: Alternative Representations of Technological Change". GLO Discussion Paper No.85.

12. Knutsen, C. H. (2011), "Which Democracies Prosper? Electoral rules, Form of Government and Economic Growth". Electoral Studies, 30(1), pp. 83-90.

13. Kurzman, C., Werum, R., and Burkhart, R. E. (2002), "Democracy's Effect on Economic Growth: A Pooled Time-Series Analysis, 19511980". Studies in Comparative International Development (SCID) , 37(1), pp. 3-33.

14. Narayan, P. K., Narayan, S., and Smyth, R. (2011), "Does Democracy Facilitate Economic Growth or Does Economic Growth Facilitate Democracy? An Empirical Study of Sub-Saharan Africa". Economic Modelling, 28(3), pp. 900-910.

15. Rachdi, H., and Saidi, H. (2015), "Democracy and Economic Growth: Evidence in MENA Countries". Procedia-Social and Behavioral Sciences, 191, pp. 616-621.

16. Salahodjaev, R. (2015), "Democracy and Economic Growth: The Role of Intelligence in Cross-country Regressions". Intelligence, 50, pp. 228-234.

17. Sirowy, L., and Inkeles, A. (1990), "The Effects of Democracy on Economic Growth and Inequality: A Review". Studies in Comparative International Development (SCID), 25(1), pp. 126-157.

18. Tang, S. H. K., and Yung, L. C. W. (2005), "Does Rapid Economic Growth Accelerate Democratization?: Time-series Evidence from High Performing Asian Economies". University of Western Australia, Business School, Economics.

19. Tavares, J., and Wacziarg, R. (2001), "How Democracy Affects Growth". European Economic Review, 45(8), pp. 1341-1378.

20. World Bank, Word Development Indicators, http://databank.worldbank.org/data/reports.aspx?source=world-development-indicators. Date Accessed: 9.12.2017. 